\title{
Development of a Novel Freeze-dried Mulberry Leaf Extract-based Transfersome Gel
}

\section{Dondurularak Kurutulmuş Dut Yaprağı Ekstresi Bazlı Yeni Bir Transferzom Jelinin Geliştirilmesi}

\author{
(1) Sopan NANGARE ${ }^{1 *}$, (1) Dhananjay BHATANE2 ${ }^{2}$, (1) Rushikesh MALI2, (1) Mayuri SHITOLE 3 \\ ${ }^{1}$ H.R. Patel Institute of Pharmaceutical Education and Research, Department of Pharmaceutical Chemistry, Dhule, India \\ 2Bharati Vidyapeeth College of Pharmacy, Department of Pharmaceutics, Maharashtra, India \\ 3Murli Krishna Pharma Pvt. Ltd., Department of Process Development Lab, Maharashtra, India
}

\begin{abstract}
Objectives: Nowadays, antioxidants are important for health-related concerns related to acne vulgaris. Acne vulgaris is interrelated with the development of free radicals that interact with cells. Mulberry leaves contain phenolic compounds, including antioxidants such as quercetin. An antioxidant is a scavenger of free radicals. The current study addresses the development of a mulberry leaf extract-based transfersome gel containing quercetin by a thin-layer hydration method for topical antioxidant delivery. The process was optimized by encapsulating the drug in a variety of transfersome formulations.
\end{abstract}

Materials and Methods: Batch optimization was carried out by particle size and zeta analysis, entrapment efficiency (\%), polydispersity index, in vitro drug release, and drug content analysis.

Results: The optimized batch MF5 provided $86.23 \%$ entrapment efficiency of quercetin in the vesicles and $95.79 \%$ drug release. It furnished a spherical shaped vesicle with an average diameter of $118.7 \mathrm{~nm}$ and zeta potential of $-45.11 \mathrm{mV}$. The MG1 formulation provided superior antioxidant activity, drug content, and entrapment efficiency, ex vivo drug release, spreadability, homogeneity, and stability to MG2. The presence of quercetin in the extract and gel formulation was confirmed by using high performance thin layer chromatography.

Conclusion: It is evident from this study that a mulberry leaf extract-based transfersome gel is a promising prolonged delivery system for quercetin and has reasonably good stability characteristics. This research recommends that mulberry leaf extract-based transfersome gel can potentially be used in the treatment of acne vulgaris through a transdermal drug delivery system.

Key words: Transfersomes, mulberry leaves, quercetin, antioxidant activity, transfersome gel

öz

Amaç: Günümüzde antioksidanlar, akne vulgaris bağlantılı sağlık sorunları için önemlidir. Akne vulgaris, hücrelerle etkileșime giren serbest radikallerin gelişimi ile ilişkilidir. Dut yaprakları, kuersetin gibi antioksidanlar da dahil olmak üzere fenolik bileşikler içerir. Bir antioksidan, serbest radikal temizleyicisidir. Bu çalışma, topikal antioksidan taşınımı için ince tabaka hidrasyon yöntemi ile kuersetin içeren dut yaprağı ekstresi bazlı transferzom jeli geliştirilmesini ele almaktadır. İşlem, ilacı çeşitli transferzom formülasyonları ile enkapsüle ederek optimize edildi.

Gereç ve Yöntemler: Seri optimizasyonu için partikül boyutu, zeta analizi, yükleme etkinliği (\%), polidispersite indeksi, in vitro ilaç salımı ve ilaç içeriği analizleri gerçekleştirildi.

Bulgular: Optimize edilmiş MF5 serisinin, enkapsülasyon etkinliği \%86,23 ve kersetin salımı \%95,79 olarak bulundu. Ortalama çapı 118,7 nm ve zeta potansiyeli -45,11 mV olan küresel șekilli morfolojiye sahip oldukları tespit edildi. MG2 formülasyonuna göre MG1 formülasyonu üstün antioksidan aktivite, ilaç içeriği, enkapsülasyon etkinliği, ex vivo ilaç salımı, dağılabilirlik, homojenlik ve stabilite sağladı. Ekstre ve jel formülasyonunda kersetin varlığı, yüksek performanslı ince tabaka kromatografisi kullanılarak doğrulandı.

Sonuç: Bu çalışmada, dut yaprağı ekstresi bazlı transferzom jelin, kuersetin için ümit verici uzun süreli ilaç salım sistemi olduğu ve oldukça iyi stabilite özelliklerine sahip olduğu belirlendi. Bu araştırma, dut yaprağı ekstresi bazlı transferzom jelin potansiyel olarak bir transdermal ilaç taşıyıcı sistem aracılığıyla akne vulgaris tedavisinde kullanılabileceğini önermektedir.

Anahtar kelimeler: Transferzomlar, dut yaprakları, kuersetin, antioksidan aktivite, transferzom jel

*Correspondence: snangareopan@gmail.com, Phone: +919561141110 ORCID-ID: orcid.org/0000-0002-6513-3336

Received: 06.08.2019, Accepted: 05.12.2019

๑Turk J Pharm Sci, Published by Galenos Publishing House. 


\section{INTRODUCTION}

In the modern era, acne is the most common skin disease worldwide.' The research scenario indicates that approximately $85 \%$ of the world's population between 11 and 30 years is affected at some point in their lifetime. Approximately 4.8 million peoples per year are affected by acne.,.3 Principally, it is a multifactorial disease of the pilosebaceous unit, which manifests as comedones or severe inflammatory lesions $s^{4,5}$ in the skin, mainly on the face. This is related to the elevated rate of sebum excretion, abnormal proliferation of keratinocytes, overload production of male hormone androgens, oil-producing glands on the face, and inflammatory response initiated by bacterial antigens and cytokines. ${ }^{6}$ In addition, oxidative stress is a major factor responsible for skin diseases such as acne. Principally, oxidative stress is initiated by free radicals/reactive oxygen species (ROS) ${ }^{7.8}$ In acne vulgaris, the sebum contains hydroxyl radicals, nitrous oxide, and ROSs such as superoxide, which creates irritation during acne, inflammation, etc. Interestingly, active ingredients in plants contain exceptional antioxidant capacity, and scientific reports have revealed that herbal formulations showed the ability to repair damage caused by ROS. Additionally, various scientific reports have revealed that natural antioxidants show fewer adverse effects than synthetic antioxidant compounds. ${ }^{8}$ The encapsulation of antiacne drugs in vesicular and particulate delivery systems is in the pioneering stage, and the substitution approach is being taken to minimize their side effects while preserving their efficacy. Presently, the development of a novel drug delivery system has the goal of high therapeutic activity along with patient compliance while conquering the penetration difficulties associated with transdermal drug delivery systems." Traditionally, Morus alba L. (mulberry), generally known as a medicinal plant, has been used. The main content of mulberry leaf extract, which is normally referred to as phenolics such as quercetin [quercetin 3-(6-malonylglucoside)], isoquercetin, rutin, and some other flavonoids, has been identified in mulberry leaves..$^{10}$ It has been used to treat inflammation, cough, hypertension, cancer, and fever due to its medicinal value. The polyphenolic compounds in mulberry leaves provide its antioxidant properties by scavenging free radicals and guard many organs against oxidative stress." The utilization of mulberry leaves in formulation development can offer several advantages such as easy availability, low cost, non-toxic formulation, and enhancement of sericulture farming. Plenty of literature has revealed that quercetin reduces the production of interleukin- 6 and the expression of metalloproteinase- 1 and, consequently, reduces inflammation and fibroblast proliferation.12 Also, as an antioxidant, quercetin scavenges ROS and ultimately repairs damaged cells. Over the past few decades, sustained and efficient drug delivery systems have gained the noteworthy attention of researchers; transdermal drug delivery is one such system that offers productive significance and advantages. ${ }^{13}$ The novel era of drug delivery introduced the use of transfersomes, developed by Gregor Cevc in the year 1991. Transferomes consist of a hydrated core surrounded by an ultra-deformable lipid layer complex. ${ }^{14}$ Generally, transfersomes are made by intercellular sealing of lipids, which increases their flexibility, reduces the risk of absolute vesicle rupture in the skin, and permits transfersomes to penetrate the natural water gradient across the epidermis following application to the skin. Transferomes can thus be utilized for the delivery of synthetic and herbal drugs. ${ }^{15.16}$ Recently, considerable attention has been focused on developing a new lipidic nanovesicle-based transdermal drug delivery system. Transfersomes are deformable and flexible and have a high affinity for penetration through the skin to the systemic circulation. Transdermal administration of transfersome vesicles offers a great advantage over other vesicles; therefore, we attempted to develop a transfersomal gel formulation of mulberry leaf extract. Subsequently, prepared transfersome gels were evaluated for entrapment efficiency, particle morphology, particle size, zeta potential, polydispersity index (PDI), swelling index, viscosity and $\mathrm{pH}$ behavior, fourier transform infrared spectroscopy (FTIR), antioxidant activity, deformability index, and penetration using Franz diffusion cells. High performance thin layer chromatography (HPTLC) was used to analyze the level of active substances contained in the extract. In conclusion, novel transfersomal prepared gel could be used to explore the application of natural mulberry leaf extract containing an antioxidant (quercetin) for the treatment of acne-like skin diseases. Also, it could overcome the drug resistivity and adverse effects of currently challenging acne therapy.

\section{MATERIALS AND METHODS}

\section{Material}

Mulberry leaves were procured from a local market in Indapur, Maharastra. Ethanol AR (70\%) and TWEEN80 were from Loba Chemie (Pvt. Mumbai). PHOSPHOLIPON 90G, Carbapol 940, PROPYLENE GLYCOL, and Formic acid were from Merk Life Sciences. Diethyl ether, Ethyl acetate, Toulene, Petroleum ether, 2,2-diphenyl-1-picrylhydrazyl (DPPH), ascorbic acid, and quercetin were from Yucca Enterprises (Mumbai).

\section{Processing and extraction of mulberry leaves}

Mulberry leaves were collected from the local market in Indapur, (MS) India, in July. Briefly, the collected leaves were washed systematically under running water to remove soil and other debris adhered to them. Clean leaves were dried, ground, and passed through a sieve ASTM \#30. Mulberry leaf powder ( $50 \mathrm{~g}$ ) was subjected to Soxhlet extraction using 70\% Ethanol AR as the solvent. ${ }^{17}$ Finally, the extract was subjected to physical and phytochemical characterization.

\section{Freeze drying (FD)}

The mulberry leaf extract solution was frozen at $-20^{\circ} \mathrm{C}$ for $24 \mathrm{~h}$ and then dried using a lyophilizer (Labconco, United Kingdom) at $0.013 \mathrm{mbar}$ pressure and $-49^{\circ} \mathrm{C}$. The obtained extract powder was milled by mortar and pestle to achieve a fine powder. 


\section{Isolation of phytoconstituents}

FD extract ( $3 \mathrm{~g}$ ) was successively extracted with $50 \mathrm{~mL}$ of petroleum ether (fraction 1), $50 \mathrm{~mL}$ of diethyl ether (fraction 2 ), and $50 \mathrm{~mL}$ of ethyl acetate (fraction 3), with the assistance of a separatory funnel. Complete extraction was ensured by repeating the extraction 3 times for every batch. Owing to the presence of fatty acids and free flavonoids, respectively, fractions 1 and 2 were rejected. As fraction 3 contained quercetin, it was further processed by concentration and hydrolyzed using $7 \%$ sulfuric acid ( $10 \mathrm{~mL} / \mathrm{g}$ extract) for up to 5 h. The hydrolyzed fraction was filtered and extracted with ethyl acetate (1:1/ thrice) via a separatory funnel. ${ }^{18}$

\section{Thin-layer chromatography}

The isolated portion was chromatographed in comparison with quercetin as a reference standard (std.) along with Silica gel G TLC plates (Indian Herbal Pharmacopeia, 2002) by using toluene:ethyl acetate:formic acid (5:4:0.2) as the mobile phase. ${ }^{19}$

\section{Ultraviolet (UV)-spectrometric analysis}

The UV spectra of the isolated quercetin from mulberry leaves, std. quercetin, and the extract were recorded using a UV-visible (Vis) spectrophotometer (Jasco V-630). ${ }^{20}$

\section{Calibration curve}

\section{Calibration curve of std. and isolated quercetin}

Five working solutions of quercetin with concentrations of 10 , $20,30,40$ and $50 \mu \mathrm{g} / \mathrm{mL}$ in methanol were prepared, and the absorbance was recorded at $246 \mathrm{~nm} \lambda$ max for each sample.

\section{FTIR spectroscopy}

The FTIR absorption spectrum of FD mulberry leaf extract was determined by ATR-FTIR (Jasco V-530 model) using the $\mathrm{KBr}$ dispersion method.

\section{Antioxidant assay}

\section{In vitro antioxidant activity by the DPPH method}

DPPH is a rapid and sensitive method to estimate the antioxidant capacity of different plant extracts. Also, the visual observation of antioxidant activity is possible. In brief, antioxidants react with DPPH, which is a steady free radical, and the DPPH is reduced to DPPH-H. Reduction in the absorbance of the solution was measured using a UV-Vis spectrophotometer at $517 \mathrm{~nm} .^{8,21}$ The potential to scavenge the DPPH radical was measured by the following formula (1).

DPPH scavenged $(\%)=\frac{\text { Absorbance of control-absorbance of test }}{\text { Absorbance of control }}$

\section{Optimization of transfersomes of FD mulberry leaf extract}

\section{Preparation of transfersomes}

Transfersomes of FD mulberry leaf extract were formulated by the thin-layer hydration method. ${ }^{22}$ The composition of transfersomes for batches MF1, MF2, MF2, MF3, MF4, MF5, and MF6 is reported in Table 1. In these techniques, phopholipon 90G (phospholipids), tween 80 (age activator), and mulberry leaf extract were added to a round bottom flask and dissolved in dichloromethane (solvent). Then, the organic solvent was evaporated by using a rotary evaporator above the lipid transition temperature at $50^{\circ} \mathrm{C}$, under reduced pressure at a velocity of 60 rpm. After complete evaporation of the solvent, a thin layer on the inner wall of the flask was observed. Then, the deposited lipid film was rehydrated using phosphate buffer $(\mathrm{pH}$ 7.4) until the entire thin layer peeled off. The rehydration process was carried out at a temperature of $37 \pm 2^{\circ} \mathrm{C}$, with rotation at $100 \mathrm{rpm}$ for $30 \mathrm{~min}$ in the absence of a vacuum. Finally, fully hydrated transfersome suspensions were collected in a vial, then the particle size of the vesicle was reduced by ultrasonication for 5 min with an amplitude of 25 .

\section{Morphological characterization}

Prepared transfersomes was subjected to morphology evaluation. Herein, the vesicular morphology of transfersomes was observed by Motic microscope.

\section{Percentage entrapment efficiency (\%EE)}

The \%EE test was performed by using an ultracentrifugation method (indirect method) at $10,000 \mathrm{rpm}$ for $10 \mathrm{~min}$ at $4^{\circ} \mathrm{C}$, which produces a supernatant as a released drug. Measurement of the total concentration of active compound was performed by dissolving a $1 \mathrm{~mL}$ suspension of transfersomes with poly (butylene succinate) $\mathrm{pH} 6.8$ in a $10 \mathrm{~mL}$ flask. The concentration measurement was performed by using UV-Vis spectroscopy at $254 \mathrm{~nm} .{ }^{23}$ The \%EE was calculated by using equation (2).

$\% \mathrm{EE}=\frac{\mathrm{C} \text { total }-\mathrm{C} \text { released }}{\mathrm{C} \text { total }} \times 100$

Where,

$\mathrm{C}_{\text {total }}:$ Total concentration of quercetin $(\mu \mathrm{g} / \mathrm{mL})$ in transfersomes.

$C_{\text {released: }}$ Untrapped concentration of active substances $(\mu \mathrm{g} / \mathrm{mL})$ in transfersomes.

\section{Optimization of transfersomes}

The number of process variables accounts for the characterization and optimization of the transfersome formulation. Herein, the batch optimization was carried out by particle size analysis, zeta potential, PDI, and \%EE. ${ }^{24}$

Table 1. Preparation of Mulberry leaf extract transfersomes

\begin{tabular}{|c|c|c|c|c|c|c|}
\hline \multirow{2}{*}{ Material name } & \multicolumn{6}{|c|}{ Concentration (\% w/w) } \\
\hline & MF1 & MF2 & MF3 & MF4 & MF5 & MF6 \\
\hline Mulberry leaf extract & 10 & 10 & 10 & 10 & 10 & 10 \\
\hline Tween 80 & 0.3 & 0.3 & 0.3 & 0.4 & 0.4 & 0.4 \\
\hline Phopholipon 90G & 2 & 2.5 & 3 & 2 & 2.5 & 3 \\
\hline Phosphate buffer (saline $\mathrm{pH} 7.4$ ) & Add 100 & Add 100 & Add 100 & Add 100 & Add 100 & Add 100 \\
\hline
\end{tabular}


In vitro drug release of transfersomes

An in vitro drug release study was performed by using modified Franz diffusion cells. A dialysis membrane (Hi-Media, Molecular weight 5.000D) was arranged between the receptor and donor compartments. Subsequently, the transfersomes of mulberry leaf extract were kept in the donor compartment, and the receptor compartment was filled sufficiently with phosphate buffer, $\mathrm{pH} 7.4$ (25 $\mathrm{mL})$. The diffusion cells were maintained at $37 \pm 0.5^{\circ} \mathrm{C}$ with constant stirring at $40 \mathrm{rpm}$ throughout the experiment. At 30, 60, 90, 120, 150, 180, 210, 240, 270, 300, and 360 min intervals, $5 \mathrm{~mL}$ aliquots were withdrawn from the receiver compartment through the side tube and again filled with $5 \mathrm{~mL}$ and analyzed for drug content by UV-Vis spectroscopy. ${ }^{25}$

\section{Preparation of transfersome gel}

Herein, we used the optimized batch of transfersomes (MF5) for preparation of the gel. A $10 \%(w / v)$ transfersome suspension was weighed for gel formation. Carbapol 940 was added to purified water with stirring and allowed to hydrate for $24 \mathrm{~h}$. The transfersome suspension was dispersed in the hydrated carbapol 940 slurry and stirred continuously for $30 \mathrm{~min}$. Then, propylene glycol was added slowly to the slurry. The $\mathrm{pH}$ of the formulation was adjusted with triethanolamine, and the same procedure was carried out for the control extract-based gel (MG2) (Table 2). ${ }^{26}$

\section{Evaluation of MG and MG2 gel formulation}

MG1 and MG2 gel formulations were subjected to organoleptic evaluation, FTIR, homogeneity rate, $\mathrm{pH}$ and viscosity measurements, flow property measurements, drug content analysis, ${ }^{27}$ and $\% E E .{ }^{28}$

\section{Homogeneity rate}

The homogeneity of the formulated gel was determined by pressing a small amount of both gels (MG1 and MG2) between the thumb and the index finger. The uniformity was a resolute as a harmonized or not. ${ }^{29}$

\section{Spreadability}

A spreadability test of MG1 and MG2 gels was carried out by pressing $0.5 \mathrm{~g}$ of the final formulation. Briefly, a sample of the gel from each batch was pressed between 2 translucent spherical glass slides, and the highest degree of spreading was permitted by leaving them for $5 \mathrm{~min}$. The diameter of the formed circle was calculated to articulate the spreadability of the formulated gel. ${ }^{30}$

\section{HPTLC analysis}

HPTLC analysis was performed by application of the std. and isolated quercetin, and MG1 formulation. The samples were prepared by using methanol. Subsequently, the analysis of quercetin was performed on the HPTLC plate of silica gel 60F254 $(5 \mathrm{~cm} \times 10 \mathrm{~cm}$ ) using a mixture of toluene:ethyl acetate:formic acid as the mobile phase in proportions of 5:4:0.2. Finally, the quercetin dark brown colored bands were identified and confirmed via $R_{f}{ }^{31}$

\section{Limit of detection (LOD) and limit of quantification ( $L O Q$ )}

LOD and $L O Q$ are 2 important terms used to describe the smallest concentration of an analyte that can be reliably measured by an analytical procedure. The $L O D$ and $L O Q$ of compounds were determined based on $R_{f}$ values as well as UV/Vis spectral overlaying of respective standard compounds. The LOD was determined based on the lowest concentration detected by the instrument from each of 2 standards, while the $L O Q$ was determined based on the lowest concentration quantified in the samples.

The determination of LOD and $L O Q$ was calculated using the formula,

$$
\begin{aligned}
& \mathrm{LOD}=1 / 43.3(\mathrm{SD} / \mathrm{S}) \ldots \ldots \ldots . .(3) \\
& \mathrm{LOQ}=1 / 410(\mathrm{SD} / \mathrm{S}) \ldots \ldots \ldots .(4)
\end{aligned}
$$

Where,

SD: Standard deviation of the response

\section{S: Slope}

\section{Drug content (\%)}

Accurate quantities of MG1 and MG2 gel were measured into in separate beakers, lysed with $50 \mathrm{~mL}$ methanol for $15 \mathrm{~min}$ using ultrasonication, and centrifuged at 10,000 rpm for 30 $\min \left(25^{\circ} \mathrm{C}\right)$. The clear supernatant was collected, added to 10 $\mathrm{mL}$ methanol, and diluted with $\mathrm{pH}$ 7.4. The quercetin content was calculated from the absorbance determined using a UV spectrophotometer at $246 \mathrm{~nm}$.

\section{Ex vivo release studies}

Fresh hairless abdominal goat skin was collected from a slaughterhouse and used for release studies after peeling the skin from the underlying cartilage placed inside the receptor compartment. ${ }^{32,33}$ In brief, using a Franz diffusion cell apparatus, the drug release studies were performed. Goat skin was placed between the donor and receptor compartments. The receptor compartment was filled with the phosphate buffer and ethanol mixture in a ratio of $8: 2(15 \mathrm{~mL})$ at $37 \pm 0.5^{\circ} \mathrm{C}$, and gel samples were exposed to the donor compartment. Receptor compartment containing dissolution media was continuouslystirred using magnetc stirrer at $25 \mathrm{rpm}$, which help to avoid the saturation of dissolution media during the penetration of the active content. ${ }^{34}$ For the calculation of percent ex vivo drug release, sampling was performed at different time intervals.

\section{Statistical analysis}

All outcomes in this work are expressed as a mean \pm SD. A paired Student's t-test was used for the comparison of percent

\begin{tabular}{|c|c|c|c|c|c|c|}
\hline Composition & \multirow{2}{*}{ Transfersomes } & \multirow{2}{*}{ Extract } & \multirow{2}{*}{ Carbapol 940} & \multirow{2}{*}{ Triethanolamine } & \multirow{2}{*}{ Propylene glycol } & \multirow{2}{*}{ Water } \\
\hline Concentration ( $\% \mathrm{w} / \mathrm{w})$ & & & & & & \\
\hline MG1 & Equal to $10 \%$ extract & - & 1 & 0.1 & 12.5 & Add 100 \\
\hline MG2 & - & 10 & 1 & 0.1 & 12.5 & Add 100 \\
\hline
\end{tabular}

Table 2. Transfersome gel of mulberry leaf extract (MG1) and control extract gel (MG2) 
ex vivo drug release of 2 related gel samples (MG1 and MG2). Differences at $p<0.05$ was considered significant.

\section{Ex vivo penetration test}

An ex vivo penetration test of the transfersome gel was carried out on fresh hairless abdominal goat skin through a Franz diffusion cell apparatus assembly. The goat skin was assembled between the donor and receptor compartment with an effective diffusion area of $2.26 \mathrm{~cm}^{2}$ and a cell volume of $25 \mathrm{~mL}$. Briefly, the receptor compartment contained phosphate buffer and ethanol (8:2) media ( $15 \mathrm{~mL}$ ) at body temperature $37 \pm 0.5^{\circ} \mathrm{C}$ and the media in the receptor compartment was stirred. The gel was placed in the donor compartment, and samplings were carried out periodically for $24 \mathrm{~h}$ from the receptor compartment. Simultaneously, the sink condition was maintained, and the collected samples were subjected to UV spectrophotometry analysis. Based on the experimental findings, the permeation coefficient was calculated by using the cumulative amounts of drug permeated per unit area $\left(\mu \mathrm{g} / \mathrm{cm}^{2}\right)$ vs time graph. The transdermal flux was calculated from the slope of the linear portion of the graph.

\section{Stability study}

MG1 and MG2 formulations were stability tested for 3 months at $4^{\circ} \mathrm{C} \pm 2^{\circ} \mathrm{C}$ and $40^{\circ} \mathrm{C} \pm 2^{\circ} \mathrm{C} 75 \% \pm 5 \% \mathrm{RH}$ stations for determination of the physical and chemical stability of the formulations (as per International Council for Harmonisation guidelines).

\section{RESULTS}

\section{Characterization of mulberry leaf extract}

The extraction was performed by the successive hot continuous Soxhlet extraction method. The ethanolic extract of mulberry leaves was greenish in color. The phytoconstituent analysis revealed the presence of sterols, tannins, phenols, and alkaloids. The $\mathrm{pH}$ of the extract was 6.5.

\section{TLC analysis}

TLC fingerprinting of mulberry leaf extracts was performed along with std. quercetin under UV 254. It showed that spots representing std. quercetin and isolated quercetin had $R_{f}$ values of 0.38 and 0.31 , respectively (Figure 1 ). In conclusion, quercetin analysis using TLC confirmed the presence of quercetin in the extract.

Subsequently, the UV spectra of std. quercetin was observed at $254 \mathrm{~nm}$, which confirmed the purity and presence of quercetin in the prepared sample (Figure 2a). Also, the UV spectra of isolated quercetin from mulberry leaf extract were obtained at $246 \mathrm{~nm}$ and confirmed the existence of quercetin in the extract (Figure 2b).

\section{Calibration curve of standard quercetin and isolated quercetin}

The calibration curve of the std. (Figure 3a) and isolated quercetin (Figure 3b) showed linearity along with 0.999 and $0.996 R^{2}$, respectively, providing confirmation of the purity of quercetin.
FTIR spectra of std and quercetin isolated from mulberry extract

FTIR investigations revealed the presence of quercetin. In brief, std. quercetin showed the peak of $\mathrm{O}-\mathrm{H}$ stretching vibration at $3387.47 \mathrm{~cm}^{-1}$, whereas $\mathrm{O}-\mathrm{H}$ bending of phenol function was detectable at $1316 \mathrm{~cm}^{-1}$. The $\mathrm{C}=\mathrm{C}$ aromatic ring stretch band was at $1605.47 \mathrm{~cm}^{-1}$. The in-plane bending band of in aromatic hydrocarbon was detectable $\mathrm{C}-\mathrm{H}$ at $1446.70 \mathrm{~cm}^{-1}$. The $\mathrm{C}=\mathrm{O}$ aryl ketonic stretch absorption was evident at $1659.83 \mathrm{~cm}^{-1}$. Bands at $1165.63 \mathrm{~cm}^{-1}$ was attributable to the $\mathrm{C}-\mathrm{O}$ stretching in the aryl ether ring (Figure 4a). The observed frequencies for isolated quercetin from the extract of mulberry leaves are shown in Figure 4b. It showed the $\mathrm{O}-\mathrm{H}$ (strong) stretching vibration at 3288.26 $\mathrm{cm}^{-1}$, and $\mathrm{C}-\mathrm{H}$ stretching vibration at $2916.94 \mathrm{~cm}^{-1}$. The $\mathrm{C}=\mathrm{O}$ aryl ketonic stretch absorption was evident at $1731.51 \mathrm{~cm}^{-1}$. The in plane bending band of in aromatic hydrocarbon was detectable $\mathrm{C}-\mathrm{H}$ bending at $1415.10 \mathrm{~cm}^{-1}$. Bands at $1026.95 \mathrm{~cm}^{-1}$ was attributable to the $\mathrm{C}-\mathrm{O}$ stretching in the aryl ether ring at $1026.95 \mathrm{~cm}^{-1}$. Overall, it provides confirmation of quercetin present in the extract (Figure 4b). These pragmatic frequencies confirmed that the isolated fraction was quercetin in reference to std. quercetin.

\section{Antioxidant activity}

The antioxidant activity of the FD extract showed an excellent result in contrast to standard ascorbic acid. Quercetin isolated from mulberry leaves, ascorbic acid (std.), and std. quercetin furnished antioxidant activity of $67.2 \%, 83.20 \%$, and $69.54 \%$

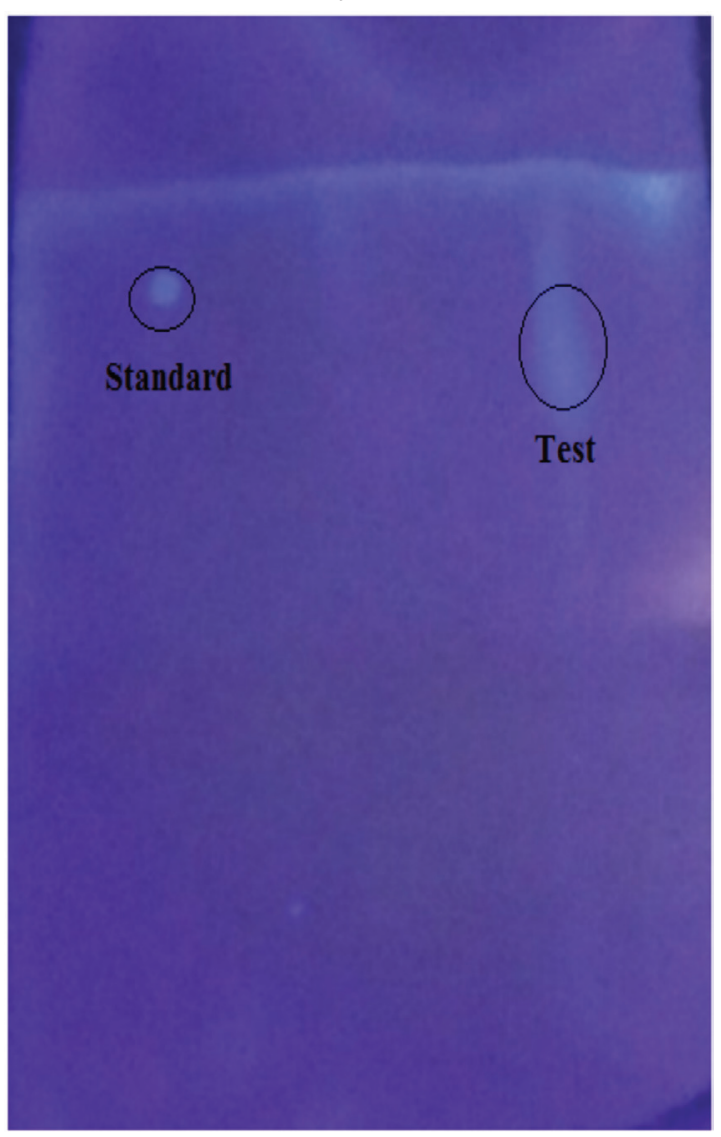

Figure 1. TLC plate developed under UV light at $254 \mathrm{~nm}$ TLC: Thin layer chromatography, UV: Ultraviolet 


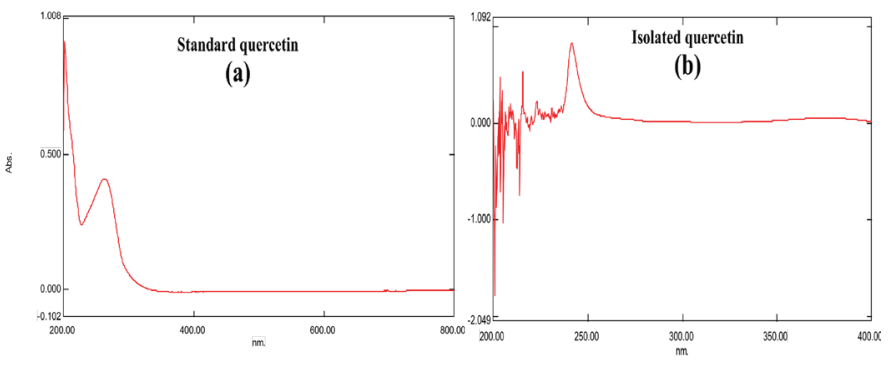

Figure 2. UV spectra of standard quercetin (a) isolated quercetin (b) UV: Ultraviolet
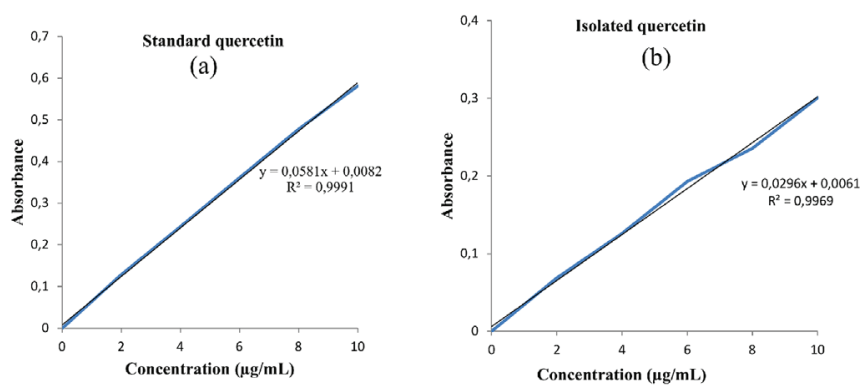

Figure 3. Calibration curve of standard quercetin (a) and isolated quercetin (b)

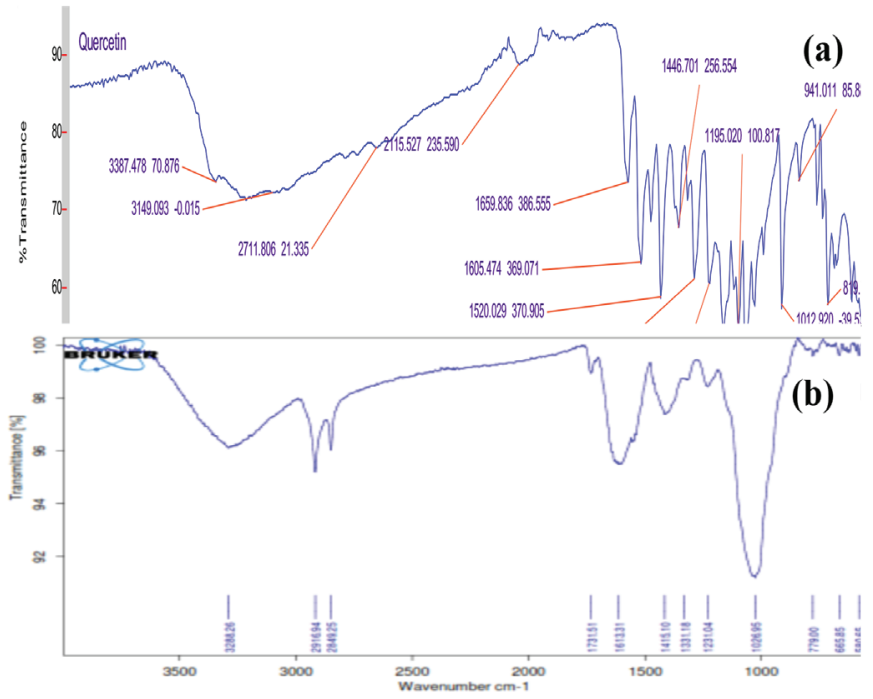

Figure 4. FTIR spectra of standard quercetin (a) and isolated quercetin (b) FTIR: Fourier transform infrared spectroscopy consistently. In conclusion, free- radical scavenging capacity of isolated quercetin and standard quercetin was found similar.

\section{Characterization and optimization of transfersomes}

\section{Shape of the vesicle}

The shape of the vesicle by Motic microscopy revealed no aggregation or irregularities in transfersomes, and the spherical structures of vesicles were observed in the range of 110 to $460 \mathrm{~nm}$ in diameter. Hence, the successful construction of transfersome vesicles was confirmed (Figure 5).

\section{Optimization of transfersomes}

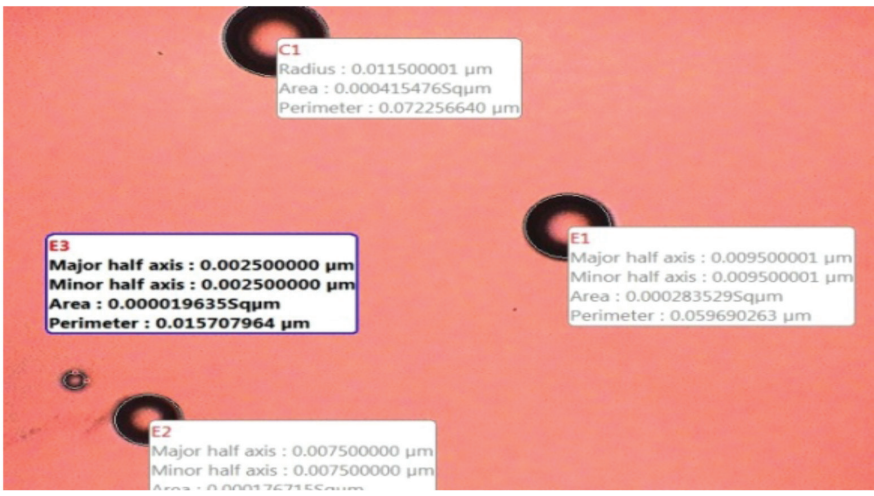

Figure 5. Unsonicated transfersomes vesicles by Motic microscopy

\section{Particles size analysis and PDI}

The size distribution of the transfersome suspension was determined by a particle size analyzer (nanoplus) which works by photon correlation spectroscopy (Table 3). Owing to the surfactant, the vesicle size observed was within the range of 114.5 to $416.6 \mathrm{~mm}$. The PDI values of the formulation were observed in the range of 0.270 to 0.628 . Based on the particle size and PDI value, it was concluded that the particle size distribution was consistent within the formulation.

\section{Zeta potential}

The Zeta potential provides knowledge of particle aggregation or flocculation in suspension. Herein, the transfersome batch (MF1 to MF6) showed a zeta potential in the range of -21.19 to -45.11 $\mathrm{mV}$. These results specify the stability of the transfersomes in a suspension.

Percent entrapment efficiency

Table 3. Characterization and optimization of prepared transfersomes

\begin{tabular}{llllll} 
Batch no & Particle size & Zeta potential & PDI & \%EE & Deformability index \\
\hline MF1 & $381.9 \mathrm{~nm}$ & $21.19 \mathrm{mV}$ & 0.511 & $68.23 \pm 1.2$ & $3.52 \pm 0.9$ \\
\hline MF2 & $214.5 \mathrm{~nm}$ & $-44.56 \mathrm{mV}$ & 0.421 & $65.23 \pm 1.1$ & $3.63 \pm 0.5$ \\
\hline MF3 & $268.3 \mathrm{~nm}$ & $-21.91 \mathrm{mV}$ & 0.448 & $76.23 \pm 0.9$ & $2.25 \pm 1.3$ \\
\hline MF4 & $401.9 \mathrm{~nm}$ & $-22.39 \mathrm{mV}$ & 0.270 & $77.65 \pm 1.6$ & $3.5 \pm 2.1$ \\
\hline MF5 & $118.7 \mathrm{~nm}$ & $-45.11 \mathrm{mV}$ & 0.389 & $86.23 \pm 2.1$ & $1.03 \pm 0.8$ \\
\hline MF6 & $416.6 \mathrm{~nm}$ & $-27.73 \mathrm{mV}$ & 0.628 & $80.23 \pm 1.8$ & $2.05 \pm 1.5$ \\
\hline
\end{tabular}

$\mathrm{n}=3, \pm$ standard deviation, $\mathrm{PDI}$ : Poly dispersity index, EE: Entropment afficiency 
\%EE was calculated by using the ultracentrifugation method. In brief, the un-entrapped drug was separated and the amount of it calculated. Subsequently, the EE was calculated for transfersomes. From the estimation of the \%EE, the MF1 to MF6 showed 57.65 to $86.23 \%$ EE.

\section{In vitro release of transfersomes}

The determination of percent drug release in phosphate $\mathrm{(pH} 7.4)$ was carried out by using the slope of quercetin in phosphate buffer ( $\mathrm{pH}$ 7.4) calibration curve (Figure 6). The comparison in vitro cumulative release from batches MF1 to MF6 in the diffusion study is shown in Figure 7; it was 90.34\%, 92.07\%, 91.69\%, 92.03\%, 95.79\%, and 91.42\%, respectively. Among all the batches, MF5 showed the highest extended-release of 95.79\% after $6 \mathrm{~h}$ (Figure 7). Herein, based on the \%EE, particle size analysis, zeta potential, and PDI, we selected the MF5 batch as the optimized batch and used it for further processes of gel formulation.

\section{FTIR spectra of transfersomes}

The FTIR spectra of transfersome gels showed peaks for $\mathrm{O}-\mathrm{H}$ stretching, $\mathrm{C}-\mathrm{H}$ stretching, $\mathrm{C}-\mathrm{O}$ stretching, $\mathrm{C}=\mathrm{O}$ stretching, $\mathrm{C}-\mathrm{H}$ bending, and C-O starching around $3334 \mathrm{~cm}^{-1}, 2923 \mathrm{~cm}^{-1}, 2853$ $\mathrm{cm}^{-1}, 1620 \mathrm{~cm}^{-1}, 1453 \mathrm{~cm}^{-1}$, and $1035 \mathrm{~cm}^{-1}$, respectively, which is

\section{Phospahte buffer (pH 7.4)}

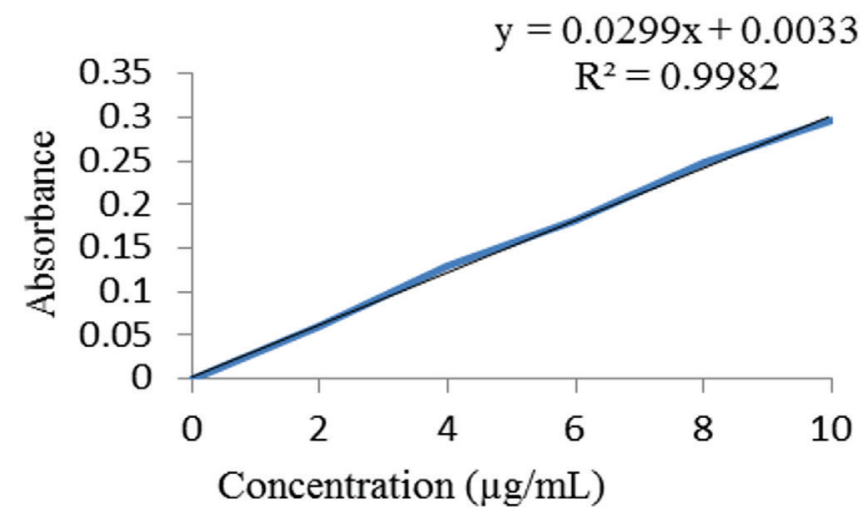

Figure 6. Calibration curve of extract $(\mathrm{pH} 7.4)$

\section{In vitro release profile of Transfersomes}

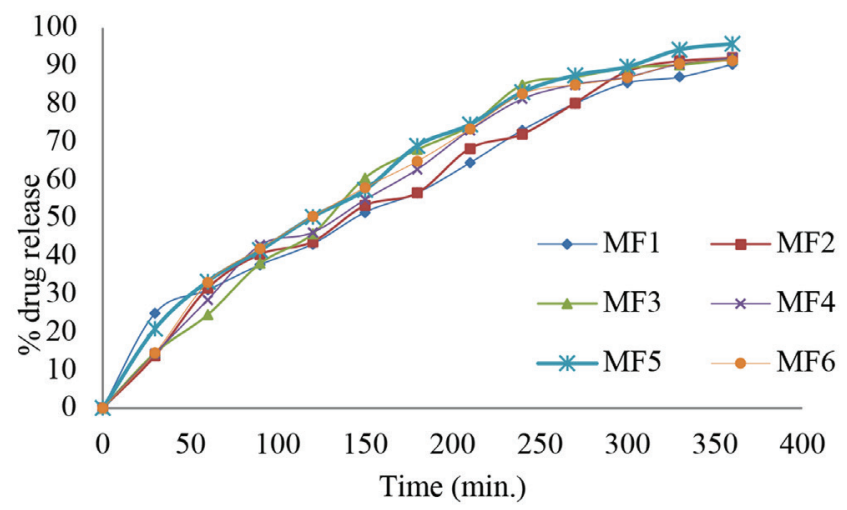

Figure 7. In vitro release profile of transfersomes about same as for std. quercetin FTIR. The appearance of the above peaks in Figure 8 confirmed the presence of quercetin and other compounds. No interaction was found between quercetin and the excipients used in formulation development.

\section{Evaluation of MG1 and MG2}

The MG2 gel showed a greenish color and a glossy appearance due to direct contact between the extract and the gel-forming agent. The MG1 gel furnished a slightly greenish color and a transparent as well as glossy appearance, because the extract was entrapped in the lipid vesicles. Both gels gave off a somewhat sweet odor and demonstrated exceptional homogeneity.

\section{Measurement of the viscosity of MG1 and MG2}

The viscosity of MG1 and MG2 gel formulations were determined by using a Brookfield Viscometer at different time intervals (Figure 9). MG1 and MG2 showed a remarkable result for viscosity. This was is because of carbopol, and it could be advantageous to resist drug leakage. Concurrently, the $\mathrm{pH}$ of the gel was determined with a digital $\mathrm{pH}$ meter (Figure 10), and it showed that MF1 gave a constant $\mathrm{pH}$ after $6 \mathrm{~h}$ and in the case of MF2, variation in the $\mathrm{pH}$ was observed.

\section{Swelling index}

The MG1 gel showed good water-holding capacity. Herein, hydrogen bonding facilitates the formation of a structure that

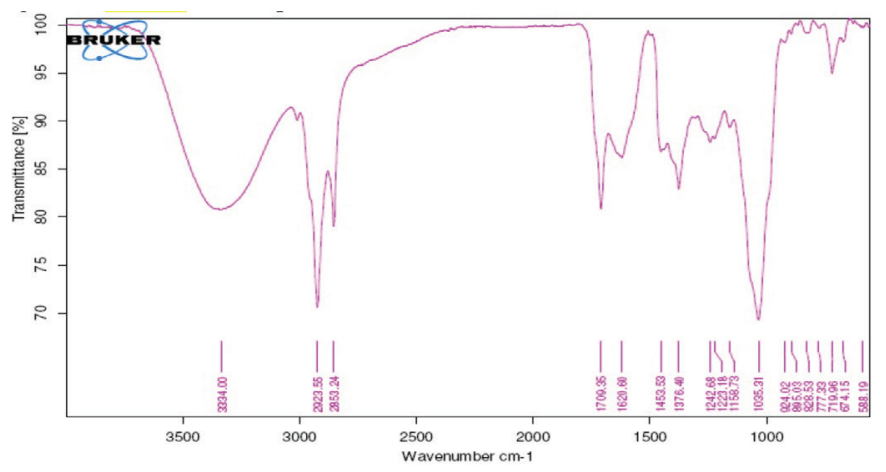

Figure 8. FTIR spectra of transfersomes FTIR: Fourier transform infrared spectroscopy

\section{Viscosity of gel}

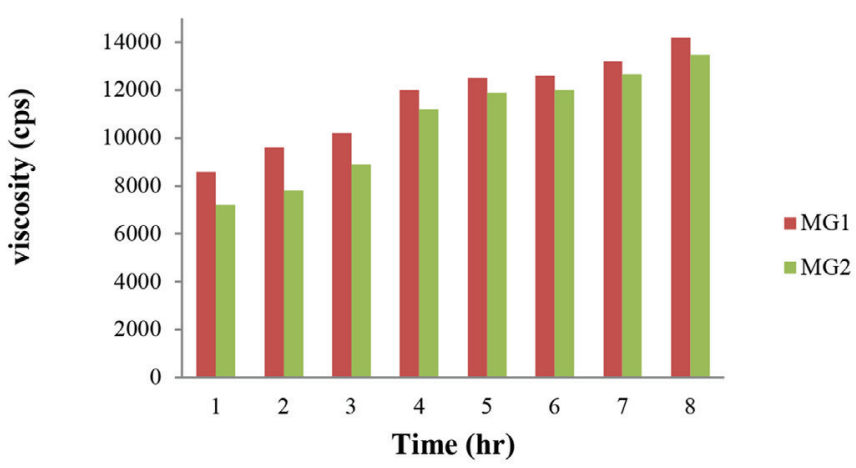

Figure 9. Viscosity of MG1 and MG2 gel 
pH of gel

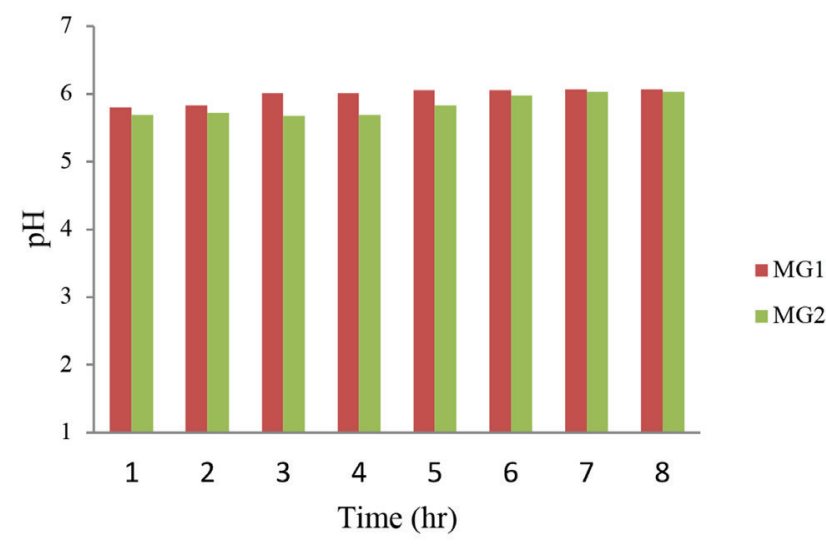

Figure 10. $\mathrm{pH}$ of MG1 and MG2 gel

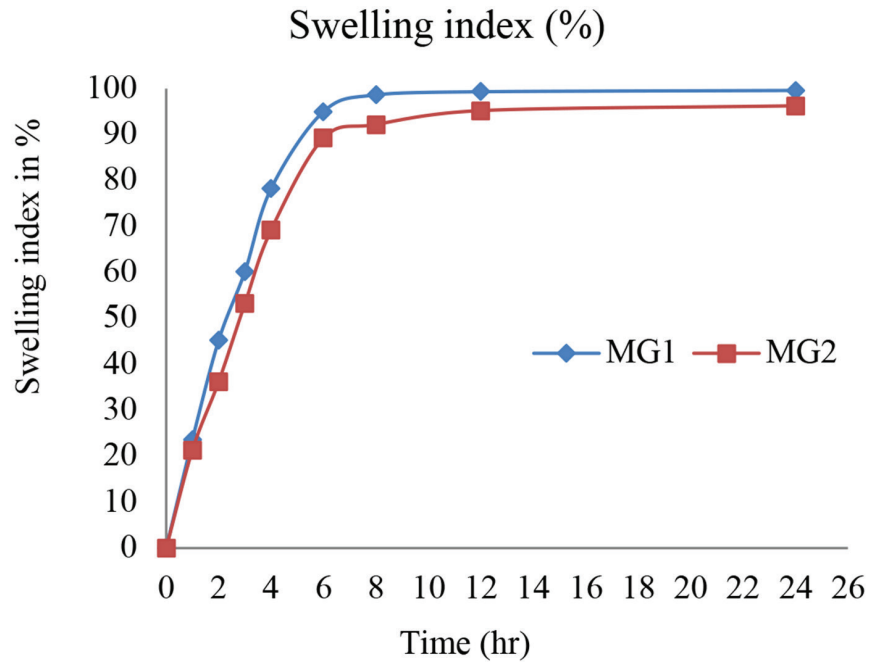

Figure 11. Swelling index of transferosomal gel

allows swelling of the excipients. A comparison of MG1 and MG2 showed a swelling index of up to $99.61 \%$ and $96.27 \%$, respectively ( $n=3$, Figure 11$)$.

\section{Flow properties}

The flow properties of MG1 and MG2 gels were computed at different day intervals. It was observed that the MG1 gel showed better flow properties than the MG2 as shown in Table 4. Outcomes of the flow properties concluded that the MG1 provides exceptional tensile strength, elongation rate, and spreadability. MG1 also exhibited a good homogeneity rate as compared with the MG2 batch.

Entrapment efficiency, drug content, and antioxidant activity The \% drug content of the MG1 and MG2 formulations was found to be $98.23 \%$ and $89.52 \%$, respectively (Figure 12a). Moreover, the MG1 gel formulation showed superior antioxidant activity (66.72\%) as compared with the MG2 gel formulation (59.23\%) as shown in Figure 12a. The MG2 gel antioxidant activity and drug content were found to be quite a bit less; this may have been because of the extract becoming degraded during the manufacturing process of the gel. The MG1 and MG2 gel formulation showed $85.6 \%$ and $81.20 \%$ EE. The formation of multi-laminar vesicle complexes in transfersomes enhances the \%EE (Figure 12b).

\section{HPTLC analysis}

Optimized parameters for std quercetin, isolated quercetin, and the gel formulation (MG1) containing quercetin by HPTLC at 246 $\mathrm{nm}$ are reported in Table 5. The spectrum scan of std. quercetin is comparable with that of an isolated compound and the formulation containing quercetin (Figure 13). For the extract, the retention time was found to be $8.4 \mathrm{~min}$, which coincided with standard quercetin. The results of tests carried on standard and isolated Quercetin and the formulation are summarized in Figure 14. It confirmed the presence of quercetin in the gel formulation, along with the absence of an interaction between excipients and quercetin.

\section{$\angle O D$ and $L O Q$}

The LOD were determined to be 0.25 and $0.23 \mathrm{ng} / \mathrm{spot}$, and the $L O Q$ was found to be 0.6 and $0.5 \mathrm{ng} / \mathrm{spot}$ for std quercetin and isolated quercetin, respectively. The values remained quite similar for both compounds, which revealed the sensitivity of the method.

\section{Ex vivo percent drug release}

The ex vivo percent drug release of MG1 and MG2 was carried out in phosphate buffer $\mathrm{pH} 7.4$ through goat skin using Franz diffusion cells (Figure 15). The dissolution profile of MG1 (96.86\%) showed an excellent drug release as compared with the MG2 (88.23\%) up to $24 \mathrm{~h}$. A statistically significant test for comparison of the ex vivo release of MG1 and MG2 was performed by a paired t-test. By conventional criteria, the considered difference between MG 1 (transferosome gel) and MG 2 (control gel) was statistically significant at the level of $p<0.05$.

Table 4. Flow properties of MG1 and MG2

\begin{tabular}{|c|c|c|c|c|}
\hline \multirow{2}{*}{ Properties } & \multicolumn{2}{|l|}{ MG1 } & \multicolumn{2}{|l|}{ MG2 } \\
\hline & 0 days & 10 days & 0 days & 10 days \\
\hline Homogeneity rate $(1 / 10 \mathrm{~mm})$ & $60.54 \pm 1.6$ & $99.58 \pm 2.9$ & $59.23 \pm 1.2$ & $99.03 \pm 3.6$ \\
\hline Elongation rate (\%) & $200.21 \pm 1.4$ & $282.3 \pm 2.5$ & $199.56 \pm 1.6$ & $276.2 \pm 3.1$ \\
\hline Spreadability (cm) & $9.80 \pm 0.9$ & $9.98 \pm 0.9$ & $8.01 \pm 0.9$ & $8.26 \pm 0.9$ \\
\hline
\end{tabular}

$\mathrm{n}=3, \pm$ standard deviation 

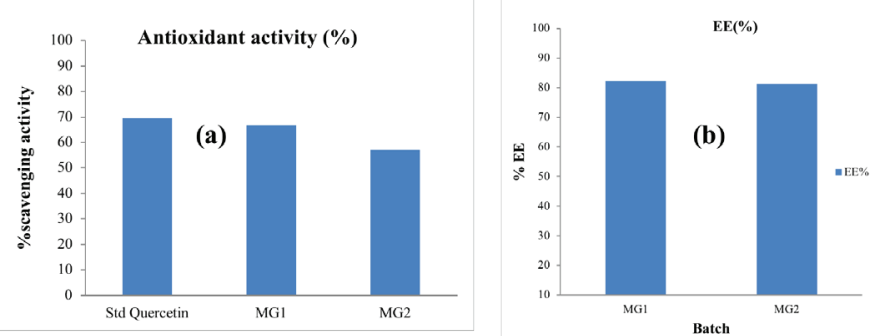

\section{Ex vivo permeation test}

The MG1 gel showed better transdermal flux as compared with the MG2 $(35.52 \pm 3.02$ and $26.01 \pm 2.02$, respectively). Moreover, a superior permeation coefficient was shown for the MG1 $(0.016 \pm 0.0009)$ than the MG2 $(0.012 \pm 0.0003)$ gel formulation.

\section{Stability studies}

After 3 months of stability testing at $4 \pm 2^{\circ} \mathrm{C}$ and $40 \pm 2^{\circ} \mathrm{C}$ in

Figure 12. (a, b) Antioxidant properties and \%EE of MG1 and MG2 gel EE: Entropment efficiency

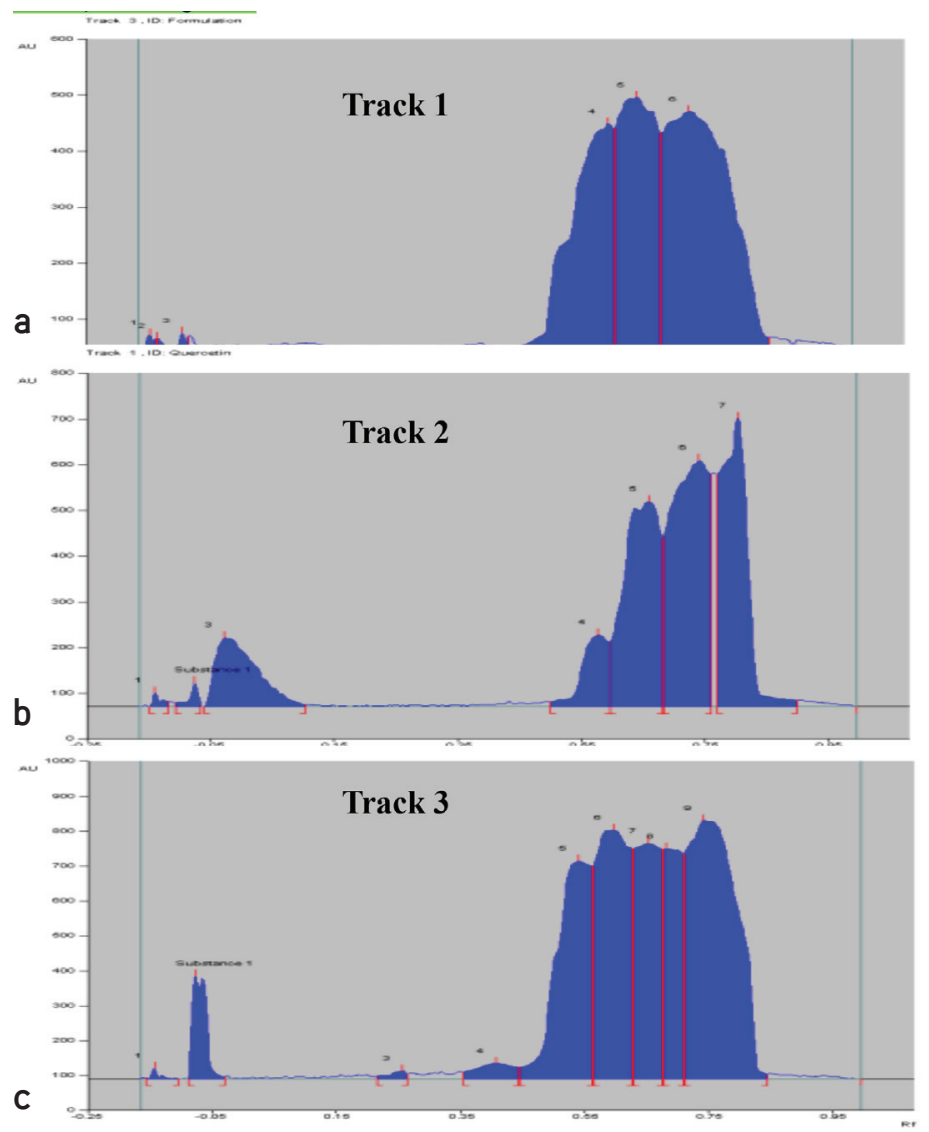

Figure 13. a) standard quercetin (track 1), b) isolated quercetin (track 2) and c) gel formulation (track 3 )

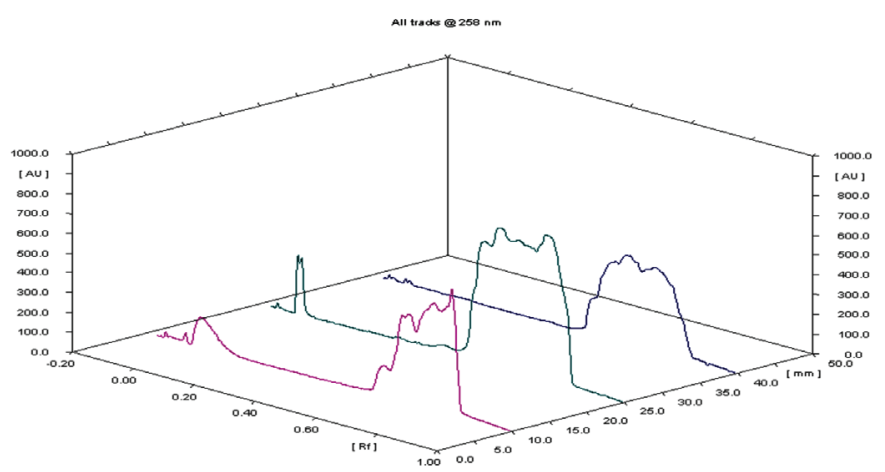

Figure 14. Overlay at $246 \mathrm{~nm}$ of standard quercetin, isolated quercetin, and formulation (MG1) in HPTLC

HPTLC: High performance thin layer chromatography sealed glass ampules, negligible drug leakage was confirmed. Based on observation, it was concluded that the MG1 gel formulation was more stable at $4 \pm 2^{\circ} \mathrm{C}$ as compared with the $40 \pm 2^{\circ} \mathrm{C}$. Furthermore, leakage of the drug from the MG1

\section{Ex vivo percent drug release}

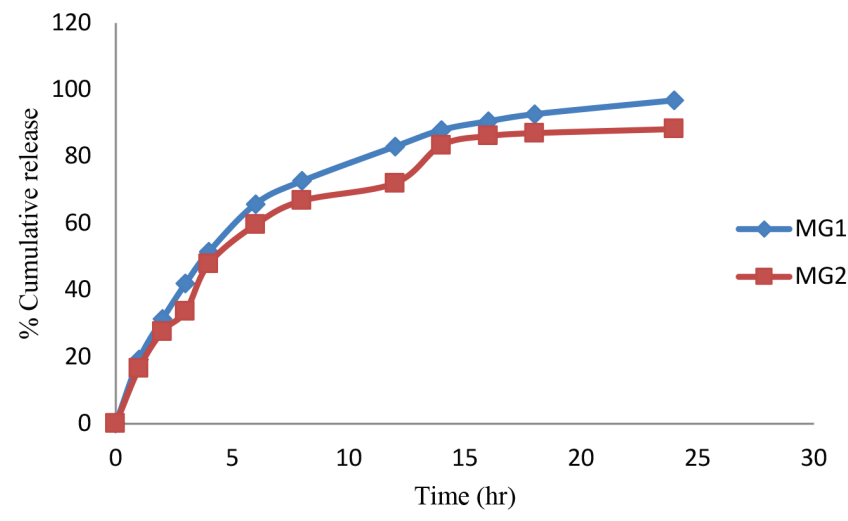

Figure 15. Dissolution profile of MG2 and MG2 gel

\begin{tabular}{|c|c|c|c|}
\hline Parameters & Description & Parameters & Description \\
\hline $\begin{array}{l}\text { Stationary } \\
\text { phase }\end{array}$ & $\begin{array}{l}\text { Merck Silica gel } \\
60 \text { F254 HPTLC } \\
\text { pre-coated } \\
\text { plates }\end{array}$ & Plate size & $4.0 \mathrm{~cm} \times 10.0 \mathrm{~cm}$ \\
\hline $\begin{array}{l}\text { Mode of } \\
\text { separation }\end{array}$ & Normal phase & $\begin{array}{l}\text { Development } \\
\text { chamber }\end{array}$ & $\begin{array}{l}\text { Camag twin } \\
\text { trough chamber }\end{array}$ \\
\hline Mobile phase & $\begin{array}{l}\text { Ethyl acetate: } \\
\text { toluene: } \\
\text { formic acid } \\
(4: 3.5: 0.5 \mathrm{v} / \mathrm{v} / \mathrm{v})\end{array}$ & Bandwidth & $7.0 \mathrm{~mm}$ \\
\hline $\begin{array}{l}\text { Chamber } \\
\text { saturation }\end{array}$ & $30 \mathrm{~min}$ & $\begin{array}{l}\text { Space } \\
\text { between the } \\
\text { bands }\end{array}$ & $7.0 \mathrm{~mm}$ \\
\hline $\begin{array}{l}\text { Sample } \\
\text { applicator }\end{array}$ & $\begin{array}{l}\text { Camag linomat } \\
\mathrm{V}\end{array}$ & Syringe & $\begin{array}{l}\text { Hamilton, } 100.0 \\
\mu \mathrm{L}\end{array}$ \\
\hline $\begin{array}{l}\text { Distance from } \\
\text { the edges of } \\
\text { the plat }\end{array}$ & $13.0 \mathrm{~mm}$ & $\begin{array}{l}\text { Rate of a } \\
\text { sample } \\
\text { application }\end{array}$ & $150 \mathrm{~nL} / \mathrm{sec}$ \\
\hline $\begin{array}{l}\text { Lamp and } \\
\text { wavelength }\end{array}$ & $\begin{array}{l}\text { Deuterium, } 246 \\
\mathrm{~nm}\end{array}$ & $\begin{array}{l}\text { Development } \\
\text { distance }\end{array}$ & $85.0 \mathrm{~mm}$ \\
\hline
\end{tabular}

Densitometric Camag scanner IV equipped with win-CATS planar scanner chromatography manager software version 1.4.7

HPTLC: High performance thin layer chromatography 
batch was found to be minimum as compared with the MG2 gel formulation at both stability stations. The viscosity of the carbopol-containing gel prevented the movement and fusion of transfersomes, which resulted in the low drug leakage in gel formulation (MG1). As compared with the drug release of the MG1 gel formulation at zero days after stability, it demonstrated excellent product stability. As a result, there is no major variation seen in MG1, before and after stability (Table 6). Hence, the MG1 transfersome-based gel formulation is more stable without causing any incompatibility, and it shows promising potential for topical application.

Table 6. Stability evaluation of transferosomal gel after 3 months

\begin{tabular}{llll} 
Properties & & \multicolumn{2}{l}{ Gel formulation } \\
\cline { 3 - 4 }$\left(4^{\circ} \mathrm{C} \pm 2^{\circ} \mathrm{C}\right)$ & a - Color & $\begin{array}{l}\text { Slightly } \\
\text { yellowish }\end{array}$ & Greenish \\
\hline & b- $\mathrm{pH}$ & $5.62 \pm 0.23$ & $5.89 \pm 0.95$ \\
\hline & c- Viscosity (CPS) & $14005 \pm 230$ & $13202 \pm 456$ \\
\hline & d- EE (\%) & $84.96 \pm 2.35$ & $78.35 \pm 3.69$ \\
\hline \multirow{2}{*}{$\left(40^{\circ} \mathrm{C} \pm 2^{\circ} \mathrm{C}\right)$} & a- - Color & $98.01 \pm 2.61$ & $89.40 \pm 3.10$ \\
\hline & b- pH & $\begin{array}{l}\text { Slightly } \\
\text { yellowish }\end{array}$ & Greenish \\
\hline & c- Viscosity (CPS) & $13750 \pm 412$ & $12889 \pm 362$ \\
\hline & d- EE (\%) & $83.69 \pm 4.02$ & $73.23 \pm 5.06$ \\
\hline & e- Drug content (\%) & $97.96 \pm 00.97$ & $84.25 \pm 2.96$ \\
\hline
\end{tabular}

$\mathrm{n}=3, \pm$ standard deviation, EE: Entrapment efficiency

\section{DISCUSSION}

Gels are a semi-solid dosage form system of drug delivery and constitute a method of good repute among novel pharmaceutical dosage forms. Nowadays, herbal nano lipid vesicle-based gel formulations are gaining attention due to their safe and effective use. In this study, the transfersomes of mulberry leaf extract were prepared by a thin-layer hydration method. Numerous investigations have revealed that quercetin has exceptional antioxidant potential and decreases the production rate of interleukin-6 and the expression of metalloproteinase-1. Consequently, it reduces inflammation and fibroblast proliferation during the healing process. Moreover, plenty of literature claims that ROS is a major factor in skin diseases (example; acne vulgaris), and antioxidant have scavenging potential against ROS. Synthetic antioxidant agents have some adverse/side effects. Thus, the nontoxic nature of herbal antioxidants such as quercetin can be effective in the treatment of acne vulgaris ${ }^{12}$. Herein, the mulberry leaves containing the active antioxidant quercetin were isolated by using TLC and HPTLC, confirmed by using UV spectroscopy and FTIR, and compared by using std quercetin. The fruitful outcomes of TLC and UV spectroscopy provide evidence of successful isolation and confirmation of the purity of quercetin. The FTIR spectra of std. quercetin, isolated quercetin, and the gel formulation (MG1) showed the confirmation of quercetin content and excipient compatibility. In the development of a transfersome formulation, various factors are important. The sizes and shape of the vesicle mainly depend on the concentration of phopholipon 90G and the concentration of surfactants. An increase in the concentration of surfactant increases the EE of vesicles and ultimately prevents drug leakage. ${ }^{35,36}$ Outcomes of the experiment are tabulated in Table 3, which reveals that the transfersomes prepared by using a specific concentration of tween 80 and phospholipid showed a superior result as compared with other formulations. Also, the proper proportion of excipients in batch MF5 showed the highest value of \%EE ( $86 \%)$. Principally, the particle size of vesicles is an important parameter in the formulation of transfersomes. Generally, particle size distribution is based on volume. Moreover, the dynamic light scattering DLS technique determines the PDI value, which generally ranges from 0 to 0.6 . If the value of PDI >0.6, it indicates that the sample has a very broad size distribution. The results showed that the PDI value of each batch changed with particle size (Table 3 ). The highest PDI value of MF6 was caused by the large particles, which were prone to aggregation. ${ }^{26,37,38}$ Zeta potential is an important parameter to describe the stability of the dispersion system. It is used to measure the magnitude of the electrostatic potential or repulsive force among the same electrical charge of particles in suspension. Also, it gives an idea that particles in suspension undergo aggregation or flocculation. Various scientific reports revealed that the zeta potential is stable when more positive than of $+30 \mathrm{mV}$ or more negative than $-30 \mathrm{mV}$. ${ }^{24,26,39}$ Herein, the results revealed that the MF5 transfersomes were more stable than other formulations because their zeta potential was comparatively high. A negative value of zeta potential might be derived from the lipid composition in the formula. Phosphatidylcholine is a zwitterionic compound with an isoelectric point of 6-7. Also, phosphate buffered saline at $\mathrm{pH} 7.4$ was used as the hydrating medium in the process of vesicle formulation. In that, the $\mathrm{pH}$ was slightly higher than the isoelectric point of phosphatidylcholine and due to this, the phosphatidylcholine carried a negative charge. ${ }^{24}$ The deformability index is an important parameter in transfersome preparation and generally is used to examine the flexibility of transfersomes. The deformability index value is influenced by the concentrations of phospholipid and surfactant used. The use of excessive surfactant can lower the deformability index value as it can lead to the formation of micelles. At a larger index value of deformability, the transfersomes will be more flexible, which will allow them to penetrate through skin pores smaller than themselves. ${ }^{40}$ The results show that MF5 transfersomes had the lowest deformability index. Based on the transfersome characterization results, batch optimization was carried out and the optimal batch further formulated into a gel. The formula selected was a batch with the highest percentage of drug entrapped, an uniform nano-size distribution, a value of the PDI more than \pm 0.30 , and a value of zeta potential more negative than $-30 \mathrm{mV}$. Based on the summary results, MF5 transfersomes was chosen because they had a spherical shape, the highest 
percentage of drug entrapped $(86.23 \pm 2.1 \%$ ), a PDI of 0.389 , a zeta potential value of -45 , a Dv90 particle size of $118.7 \mathrm{~nm}$, and a deformability index of $1.03 \pm 0.8$. Simultaneously, mulberry leaf extract-based gel (MG2) was prepared for evaluation and comparison with MG1. FTIR of the MG1 gel confirmed that there was no interaction between quercetin and excipients. Besides, the MG1 gel formulation showed satisfactory flow properties, viscosity, and stable pH. Also, MG1 gel showed a superior swelling index and the homogeneity rate. The antioxidant assay of MG1 gel showed that the good antioxidant activity as compared with the MG2. In the MG2 formulation, there may be a chance of degradation or interaction between quercetin and excipients and, due to that, the antioxidant activity is slightly diminished. HPTLC analysis was used for further phytochemical and pharmacological investigation of the gel formulation. In the present study, the phytochemical constituent (quercetin) was identified and confirmed based on the color zone obtained during the HPTLC analysis. The color of the zone with isolated quercetin and transferosomes gel formulation the color of the reference compound (std. quercetin) under daylight and UV light after derivatization in the chromatogram confirmed the presence of stable and pure quercetin. This detailed chemical profile may be useful in the identification and quality evaluation of drugs concerning plants. Ex vivo percent drug release results conducted on transfersome and control gels showed a significant difference $(p<0.05)$. Furthermore, the penetration rate of MG1 was higher vs MG2. These fruitful findings could be related to the negative charge of transfersomes. ${ }^{41}$ These negative charges generated the weak electrostatic repulsion between transfersomes and intercellular components of the skin. Subsequently, this repulsion accelerates the penetration of negatively charged transfersomes through follicles of different skin layers. Additionally, the rapid penetration of transfersomes into the intact part of the basal area of follicles occurred. ${ }^{42}$ Herein, the hydration and rehydration temperature, as well as rpm used for the development of transfersomes are key parameters in the penetration mechanism of transfersomes. Also, the phase transition temperature of the surfactant, hydrophile-lipophile balance value of the surfactant, saturation, and unsaturation of alkyl chain length play major roles in the penetration mechanism. The prepared M1 gel showed less drug release as compared with the control formulation. A possible reason involved less leakage from vesicles of transfersomes and greater hydration temperature than the gel to liquid phase transition temperature, and along with that, it provides a superior \%EE.43,44 The stability study revealed that the MG1 gel formulation had admirable stability at $4^{\circ} \mathrm{C} \pm 2^{\circ} \mathrm{C}$ and $40^{\circ} \mathrm{C} \pm 2^{\circ} \mathrm{C}$. The outcomes of the present investigation confirmed that transfersomes of mulberry leaf extract in a gel system offer a new substitute for transdermal drug delivery. Thus, based on the prolific findings, the MG1 gel formulation could be utilized in the treatment of acne.

\section{CONCLUSION}

The present study revealed the development of a novel transferosome gel of mulberry leaf extract, with enhanced antioxidant activity as compared with MG2 gel. The optimized batch of transfersomes confirms the excellent zeta potential, particle size, EE (\%), Pl, deformability index, and in vitro percent drug release. Moreover, the MG1 gel ex vivo drug release and penetration studies indicated that the developed transfersome gel formulation may serve as a promising carrier for better penetration through the skin as compared with the MG2. Although MG1 gel demonstrated good homogeneity, spreadability, excipient compatibility, and drug content as compared with the MG2, the percent EE and antioxidant properties of MG1 were admirable. Consequently, MG1 batch transfersome gel of mulberry leaf extract offers tremendous antioxidant potential, which creates new opportunities for the topical application for the treatment of acne vulgaris.

\section{ACKNOWLEDGMENTS}

The authors wish to thank Ms. Neha Desai, Assistant Professor (Ashokrao Mane College of Pharmacy, Peth-Vadgaon) for her technical support.

Conflicts of interest: No conflict of interest was declared by the authors. The authors alone are responsible for the content and writing of the paper.

\section{REFERENCES}

1. Prabu SL, Umamaheswari A, Rajakumar S, Bhuvaneswari P, Muthupetchi S. Development and Evaluation of Gel Incorporated with Synthesized Silver Nanoparticle from Ocimum gratissimum for the Treatment of Acne Vulgaris. American Journal of Advanced Drug Delivery. 2017;5:107-117.

2. Vats A, Sharma P. Formulation and evaluation of topical anti acne formulation of coriander oil. International Journal of Pharmacy and Pharmaceutical Science Research. 2012;2:61-66.

3. Baghel S, Gidwani B, Gupta A. Novel drug delivery systems of herbal constituents used in acne. International Journal of Contemporary Research and Review. 2017;7:57-67.

4. Latter G, Grice JE, Mohammed Y, Roberts MS, Benson HAE. Targeted Topical Delivery of Retinoids in the Management of Acne Vulgaris: Current Formulations and Novel Delivery Systems. Pharmaceutics. 2019;11:490.

5. Ghovvati M, Afshari GK, Nasrollahi SA, Firooz A, Samadi A, Karimi M, Talebi Z, Kolahdooz S, Vazirian M. Efficacy of topical cinnamon gel for the treatment of facial acne vulgaris: A preliminary study. Biomedical Research and Therapy. 2019;6:2958-2965.

6. Tahir CM. Pathogenesis of acne vulgaris: simplified. Journal of Pakistan Association of Dermatology. 2016;20:93-97.

7. Baek J, Lee MG. Oxidative stress and antioxidant strategies in dermatology. Redox Rep. 2016;21:164-169.

8. Vora J, Srivastava A, Modi H. Antibacterial and antioxidant strategies for acne treatment through plant extracts. Informatics in Medicine Unlocked. 2018;13:128-132.

9. Thakur N, Jain P, Jain V. Formulation development and evaluation of transferosomal gel. Journal of Drug Delivery Therapeutics. 2018;8:168177. 
10. Bown D. The Royal Horticultural Society encyclopedia of herbs \& their uses: Dorling Kindersley Limited; 1995.

11. Pujari A, Jadhav N. Design and development of anti-diabetic tablet formulation containing spray dried extract of mulberry leaves. Int J Pharm Sci Res. 2019;10:1501-1509.

12. Lubtikulthum P, Kamanamool N, Udompataikul M. A comparative study on the effectiveness of herbal extracts vs $2.5 \%$ benzoyl peroxide in the treatment of mild to moderate acne vulgaris. J Cosmet Dermatol. 2019;18:1767-1775.

13. Bhasin B, Londhe VY. An overview of transfersomal drug delivery. International Journal of Pharmaceutical Sciences and Research. 2018;9:2175-2184

14. Vinod KR, Kumar MS, Anbazhagan S, Sandhya S, Saikumar P, Rohit RT, Banji D. Critical issues related to transfersomes - novel vesicular system. Acta Sci Pol Technol Aliment. 2012;11:67-82.

15. Rajan R, Jose S, Mukund VP, Vasudevan DT. Transferosomes - A vesicular transdermal delivery system for enhanced drug permeation. J Adv Pharm Technol Res. 2011;2:138-143.

16. Malakar J, Sen SO, Nayak AK, Sen KK. Formulation, optimization and evaluation of transferosomal gel for transdermal insulin delivery. Saudi Pharm J. 2012;20:355-363.

17. Zou Y, Liao S, Shen W, Liu F, Tang C, Chen CY, Sun Y. Phenolics and antioxidant activity of mulberry leaves depend on cultivar and harvest month in Southern China. Int J Mol Sci. 2012;13:16544-16553.

18. Sanghavi N, Srivastava R, Malode Y. Isolation and identification of the flavonoid "quercetin" from tridax procumbens linn. International Journal of Pharmaceutical Sciences and Research. 2014;5:1454-1459.

19. Sajeeth C. Quantitative estimation of gallic acid, rutin and quercetin in certain herbal plants by HPTLC method. Der Chemica Sinica. 2010;1:8085.

20. Patil V, Angadi S, Devdhe S. Determination of quercetin by uv spectroscopy as quality control parameter in herbal plant: Cocculus hirsutus. J Chem Pharm Res. 2015;7:99-104.

21. Iqbal S, Younas U, Sirajuddin, Chan KW, Sarfraz RA, Uddin K. Proximate composition and antioxidant potential of leaves from three varieties of Mulberry (Morus sp.): a comparative study. Int J Mol Sci. 2012;13:66516664.

22. Chauhan P, Tyagi BK. Herbal novel drug delivery systems and transfersomes. Journal of Drug Delivery and Therapeutics. 2018;8:162168.

23. Rahmi AD, Pangesti DM. Comparison of the Characteristics of Transfersomes and Protransfersomes Containing Azelaic Acid. J Young Pharm. 2018;10:S11-15.

24. Duangjit $S$, Opanasopit $P$, Rojanarata T, Ngawhirunpat T. Characterization and In Vitro Skin Permeation of Meloxicam-Loaded Liposomes versus Transfersomes. J Drug Deliv. 2011;2011:418316.

25. Laxmi M, Zafaruddin M. Design and characterization of transferosomal gel of repaglinide. Int Res J Pharm. 2015;6:37-41.

26. Surini S, Djajadisastra J. Formulation and in vitro Penetration Study of Transfersomes Gel Containing Gotu Kola Leaves Extract (Centella asiatica L. Urban). J Young Pharm. 2018;10:27-31.

27. Ali MFM, Salem HF, Abdelmohsen HF, Attia SK. Preparation and clinical evaluation of nano-transferosomes for treatment of erectile dysfunction. Drug Des Devel Ther. 2015;9:2431-2447.
28. Laxmi M, Zafaruddin M, Kuchana V. Design and characterization of transferosomal gel of repaglinide. Int Res J Pharm. 2015;6:37-41.

29. Preeti MSK. Development of celecoxib transfersomal gel for the treatment of rheumatoid arthritis. Indian J Pharm Biol Res. 2014;2:7-13.

30. Mulani H, Bhise K. QbD Approach in the formulation and evaluation of Miconazole Nitrate loaded ethosomal cream-o-gel. Int Res J Pharm Sci. 2017;8:1-37.

31. Movaliya V, Zaveri M. HPTLC method development and estimation of quercetin in the alcoholic extract of Aerva javanica root. Advance Research in Pharmaceuticals and Biologicals. 2012;2:222-228.

32. Patel R, Singh S, Singh S, Sheth N, Gendle R. Development and characterization of curcumin loaded transfersome for transdermal delivery. J Pharm Sci Res. 2009;1:71-80.

33. Kaza R, Pitchaimani R. Formulation of transdermal drug delivery system: matrix type, and selection of polymer-their evaluation. Kaza R, Pitchaimani R. Formulation of transdermal drug delivery system: matrix type, and selection of polymer- their evaluation. Curr Drug Discov Technol. 2006;3:279-285.

34. Marwah H, Garg T, Rath G, Goyal AK. Development of transferosomal gel for trans-dermal delivery of insulin using iodine complex. Drug Deliv. 2016;23:1636-1644.

35. Jain S, Jain P, Umamaheshwari R, Jain N. Transfersomes-a novel vesicular carrier for enhanced transdermal delivery: development, characterization, and performance evaluation. Drug Dev Ind Pharm. 2003;29:1013-1026.

36. Lichtenberg D, Robson RJ, Dennis EA. Solubilization of phospholipids by detergents. Structural and kinetic aspects. Biochim Biophys Acta. 1983;737:285-304.

37. Ascenso A, Raposo S, Batista C, Cardoso P, Mendes T, Praça FG, Bentley MV, Simões S. Development, characterization, and skin delivery studies of related ultradeformable vesicles: transfersomes, ethosomes, and transethosomes. Int J Nanomedicine. 2015;10:5837-5851.

38. Malvern A. Basic Guide to Particle Characterisation. Malvern Instruments, Ltd.: Malvern, UK; 2012.

39. Liu J, Hu G. Advances in studies of phospholipids as carriers in skin topical application. Journal of Nanjing Medical University. 2007;21:349353.

40. Chaudhary H, Kohli K, Kumar V. Nano-transfersomes as a novel carrier for transdermal delivery. Int J Pharm. 2013;454:367-380.

41. Mitkari B, Korde S, Mahadik K, Kokare C. Formulation and evaluation of topical liposomal gel for fluconazole. Indian J Pharm Educ Res. 2010;44:324-333.

42. Shaji J, Lal M. Novel double loaded transferosomes: evidence of superior anti-inflammatory efficacy-a comparative study. Int J Curr Pharm Res. 2014;6:16-25.

43. Sultana SS, Krishna Sailaja A. Formulation and evaluation of diclofenac sodium transferosomes using different surfactants by thin film hydration method. Der Pharmacia Lettre. 2015;7:43-53.

44. Gupta A, Aggarwal G, Singla S, Arora R. Transfersomes: a novel vesicular carrier for enhanced transdermal delivery of sertraline: development, characterization, and performance evaluation. Sci Pharm. 2012;80:1061-1080. 